\title{
Narratives of bullying and emersion of self-compassion expressions in adolescents
}

\author{
Francisca Valda Gonçalves' \\ Nicolas de Oliveira Cardoso ${ }^{1}$ \\ Irani Iracema de Lima Argimon ${ }^{1}$ \\ ${ }^{1}$ Pontifícia Universidade Católica do Rio Grande do Sul, Porto Alegre, Brasil
}

\begin{abstract}
This study aimed to investigate the narratives of bullying and the expression of self-compassion in statements written by adolescents as a possible coping strategy. Participated 162 adolescents from a state in northern Brazil. The data collected in written testimonials were categorized based on Bardin's Content Analysis. The instructions provided for preparing the testimonies supported the structuring of four categories: 1) bullying experience; 2) reasons for bullying; 3) consequences of bullying; 4) coping strategies and self-compassion expressions. The results suggest $63.7 \%$ of adolescents witnessed bullying behaviors. Physical characteristics were the main motivation reported toward bullying. Negative feelings and psychosomatic symptoms were the main consequences reported. The adolescents reported forms of self-compassion as a coping resource before receiving psychoeducation about the concept. The implications of these findings and the use of psychoeducational interventions on bullying and self-compassion are discussed.
\end{abstract}

Keywords: coping; school; adolescents; bullying; compassion.

Narrativas de bullying e emersão de expressões autocompassivas em adolescentes

\section{Resumo}

Esse estudo objetivou investigar as narrativas de bullying e a expressão da autocompaixão, em depoimentos escritos por adolescentes, como possível estratégia de enfrentamento. Participaram 162 adolescentes de uma escola estadual do norte do Brasil. Os dados coletados por escrito foram categorizados com base na Análise de Conteúdo de Bardin. As instruções fornecidas para elaboração dos depoimentos fundamentaram a estruturação de quatro categorias: 1) vivências de bullying; 2) motivos para o bullying; 3) consequências do bullying; 4) estratégias de enfrentamento e expressões autocompassivas. Os resultados sugerem que $63,7 \%$ dos adolescentes presenciaram comportamentos de bullying. Características físicas foram percebidas como motivo para realização de bullying. Sentimentos negativos e sintomas psicossomáticos foram as principais consequências relatadas. Os adolescentes reportaram formas de autocompaixão como recurso de enfrentamento antes de receberem psicoeducação sobre o conceito. As implicações desses achados e a utilização de intervenções psicoeducativas sobre bullying e autocompaixão são discutidas. Palabras clave: enfrentamento, escola, adolescentes, bullying, compaixão.

\section{Narraciones de bullying y aparición de expresiones autocompasivas enadolescentes}

\section{Resumen}

Este estudio tuvo como objetivo investigar los relatos de bullying, y la expresión de la autocompasión en testimonios escritos por adolescentes como posible estrategia de afrontamiento. Participaron 162 adolescentes de una escuela pública del norte de Brasil. Los datos recopilados por escrito fueron categorizados según el Análisis de Contenido de Bardin. Las instrucciones proporcionadas para la elaboración de los testimonios fundamentaron la estructuración de cuatro categorías: 1) experiencias de bullying; 2) razones para el bullying; 3) consecuencias del bullying; 4) estrategias de afrontamiento y expresiones de autocompasión. Los resultados sugieren que $63,7 \%$ de los adolescentes presenciaron conductas de bullying. Las características físicas fueron percibidas como la razón del bullying. Los sentimientos negativos y los síntomas psicosomáticos fueron las consecuencias. Los adolescentes reportaron formas de autocompasión como recurso de afrontamiento antes de recibir psicoeducación sobre el concepto. Se discuten las implicaciones de estos hallazgos y el uso de intervenciones psicoeducativas sobre bullying y autocompasión. Palabras clave: afrontamiento; escuela; adolescentes; bullying; compasión.

\section{Introduction}

In the last two decades, the rates of violence and bullying in the school environment have increased (Boulton M. \& Boulton L., 2017), and in some cases with expressive notoriety in the media due to its tragic burden (e.g. suicides and armed attacks) (Livingston,
Rossheim, \& Hall, 2019). In this context, the massacres in Realengo (Rio de Janeiro) in 2015 (Pigozi \& Machado, 2015) and, in Suzano (São Paulo) integrate Brazil into the world statistics of violence.

Adolescents are the most vulnerable group to violence, with increased susceptibility due to the intensity of social interactions and for the challenges regarding 
the construction of identity at this stage of development (Fikkers, Piotrowski, Lugtig, \& Valkenburg, 2016). In response to this situation, current studies performed in several countries, such as the United States (Boulton M. \& Boulton L., 2017), Austria (Matischek-Jauk, Krammer, \& Reicher, 2017), and South Africa (Naidoo, Satorius, Vries, \& Taylor, 2016) are using psychoeducational interventions as a tool to raise awareness and develop conflict resolution skills among adolescents. When available to the school environment, such strategies are resources to promote the well-being and health of adolescents. In addition, psychoeducational interventions address one or several themes at the same time (e.g. violence, bullying, cyberbullying, psychosocial health, social skills) (Matischek-Jauk et al., 2017; Naidoo et al., 2016).

However, recent systematic reviews indicate the lack of intervention strategies for bullying in the Brazilian scenario (Pureza, Marin, \& Lisboa, 2016; Gonçalves, Cardoso, \& Argimon, 2019). In order to improve solutions for the Brazilian reality, researchers have applied the theoretical postulates of Positive Psychology with a focus on personal strengths (Rodrigues, 2015). Thus, self-compassion is a promising strategy to improve psychological well-being (García-Campayo, Martí, \& Demarzo, 2018).

Self-compassion represents a warm attitude and acceptance of the negative aspects of self or life, involving three elements: self-kindness, common humanity, and mindfulness. Self-compassionate individuals in experiences of inadequate can have an understanding and tolerant attitude, recognizing that being imperfect and making mistakes is a common human experience (Neff \& Germer, 2019). Self-compassion is related to understanding oneself in the process of suffering or inadequacy. Also, the awareness that suffering is an experience for every individual, no need to deny or immerse in negative thoughts, but to accept without judgments (GarcíaCampayo et al., 2018).

Positive Psychology suggests the development and strengthening of functional aspects can prevent problems throughout the life cycle without ignoring the difficulties that human beings face during life (Snyder \& Lopez, 2009). Characteristics such as empathy, friendship, and coping strategies focused on problem-solving strengthen the ability of self-compassion, important for preventing bullying; thus, contributing significantly to the strengthening of long-lasting prosocial behaviors in groups of interaction, reducing the practice of bullying and other violent behaviors in the school context (Petrucci \& Borsa, 2016).

However, few studies have investigated the association between self-compassion and bullying in adolescents, since the studies assess self-compassion only quantitatively using psychometric instruments (Gonynor, 2016; Zhang \& Wang, 2019). In addition, Brazilian studies that qualitatively measure the use of self-compassion as a possible strategy for coping with bullying were not found. Therefore, this study aimed to investigate the narratives of bullying and the expression of self-compassion in statements written by adolescents as a possible coping strategy.

\section{Method}

This study discusses the qualitative analysis (content analysis) of the statements developed by adolescents during a psychoeducational intervention.

\section{Participants}

The psychoeducational intervention was performed with 270 adolescents aged 12 to 16 years. Thus, 162 individuals participated in the three meetings, two on bullying and one on self-compassion, and 108 individuals in two meetings on bullying. The data analyzed in this study refer to 162 adolescents who participated in the three meetings, 74 boys and 88 girls.

\section{Data collection procedures}

Data were collected in a public school located in the northern region of Brazil. Students from neighboring and distant neighborhoods attend the school, adding students from different socioeconomic profiles. During the data collection period, the school had approximately 2.100 students enrolled for Elementary, High School, and Adult Education.

Data collection was performed at school and during psychoeducational meetings, conducted by a trained team. The school board, parents, and students who agreed to participate received information about the research objectives and procedures. The adolescents were informed about the possibility of interrupting the activity any time if they feel uncomfortable during any stage of psychoeducation.

At the time of writing the testimonies, the participants were instructed to ensure anonymity. The only possible identification is related to sex since the boys wrote their testimonies on a white paper and the girls on a green paper. This research was approved by the 
Ethics Committee of the Pontifical Catholic University of Rio Grande do Sul (PUCRS) and registered under number CAAE 79243817.50000.5336.

\section{Psychoeducation}

The intervention was applied in three meetings to groups of up to 20 participants by convenience, mediated by a team of three teachers and three students from the last year of High School. This team participated in four preparatory study meetings to read and reflect on bullying and self-compassion, and to prepare support material (presentation, videos, and music). This experience of working with a team of tutors from the school (students and teachers) has been performed in anti-bullying intervention projects with promising results in other countries (Boulton M. \& Boulton L., 2017; Matischek-Jauk et al., 2017; Naidoo et al., 2016).

The meetings occurred at the school in the second semester of 2018, on Tuesdays and Thursdays, lasting 90 minutes. The schedule was prepared with the management team and the pedagogical supervision of the school. The meetings were structured as follows:

1st Meeting (theme "Bullying in the school environment") - the beginning of psychoeducation with the explanation of the activity objective by a presentation about the concept of bullying (e.g. characteristics, scenarios, forms, prevalence, types, profile, and consequences). Comments and questions from the participants were performed during the presentation. In the end, the adolescents were asked to answer questions about bullying.

2nd Meeting (theme "Bullying in the school environment 02 ") - the reflection from the previous meeting was resumed. Then, the presentation of the concept of bullying was suggested as a rap song, the preferred music style for school teenagers. Aspects related to the rap melody and how to build the rhymes in the composition were explained: structure, metric and beat. The teenagers were organized in pairs with the proposal to write at least two verses of rap lyrics on the topic of bullying at school. In the end, some participants sang: bullying is very bad/ those who practice it think they are glad. Many people can get hurt. We need to learn how to love [...] (K. O.); those who are bullied should report/ and teachers should support (C.S).

3rd Meeting (theme "Take care of yourself") - a video was presented with the story of two teenagers who suffered bullying at school, but managed to overcome it with the help of family, friends, and a song/ testimony with a rap melody accepted at a music festival.
After the projection of the video, the participants were instructed to report in written testimonies if they had already suffered, witnessed, or defended a colleague victim of bullying, explaining how it happened and the consequences of bullying. They could also inform how they had faced such situation and leave an anonymous message to a colleague that had or are experiencing this issue.

Some statements were read by the mediators and discussed with the entire group, expressing opinions, and sharing feelings. The team emphasized the importance of mutual respect, responsibility for listening to the situations presented, and the reflection made within the group should be confidential. Self-compassion permeated the entire direction of the session without being explicitly conceptualized until the end of the meeting. Then, self-compassion was explained through images and texts, presenting the speeches of the adolescents as examples to demonstrate the importance of this resource.

\section{Data categorization and analysis}

Considering the collected information profusion (i.e. number of testimonials), the Bardin's Content Analysis (1977/2016) was performed as a resource to categorize and collate the data, thus aiming to deepen the topic under discussion.

The data were organized based on the reading of the testimonies. The reductive statements were grouped semantically, and the valid information was added in categories. Records of speeches not related to bullying and self-compassion in the school environment and not objectively and clearly identifiable with the category were excluded. From a linguistic point of view, considering that the written record of the testimonies was close to speech (Marcuschi, 2010), the texts were not corrected, or the semantic content changed.

The categories were formulated respecting the following criteria: a) Mutual exclusion - each information classifiable in only one category; b) Homogeneity - a single principle in the organization of the categories related and circumscribed to the study theme: bullying and self-compassion; and c) Pertinence - the relevance of categories within the theoretical framework of bullying and self-compassion (Bardin, 1977/2016).

\section{Results and discussion}

Initially, 21 statements were excluded for not containing content related to bullying and self-compassion 
(e.g. family problems). The remaining 141 testimonies were grouped into four categories defined a priori: 1) Bullying experiences; 2) Reasons for bullying; 3) Consequences of bullying; 4) Coping strategies and self-compassion expressions.

Each category was described and discussed separately. In addition, Table 1 shows the reporting frequency related to each of the elaborated categories, the overall percentage, and sex. Each of the reports was extracted from the testimony of participants, and some testimonies addressed issues related to two or more categories. Therefore, the testimonies were counted once in different categories, never twice within the same category.

Table 2 presents the most significant examples and the number of reports within each category and subcategory.

\section{Bullying experiences}

This category presents information from the participants regarding having suffered, witnessed, or defended a colleague who has already been bullied at school. Of the 141 participants, 61.7\% report experiencing some situation of bullying in the school environment. These numbers concern both the direct form, suffering bullying $(n=70)$, or indirectly, witnessing a colleague being assaulted $(n=12)$ or even defending that colleague $(n=05)$.

\section{Suffering bullying}

In most statements $(n=70)$, phrases were observed indicating that adolescents were victims of bullying at some point in their lives. Regarding the prevalence percentage, approximate data was released in a survey by the United Nations Children's Fund (UNICEF, 2017) on school violence in Brazil. In the survey, $43 \%$ of students aged 11 to 12 years old reported having been provoked, threatened, isolated, or forced to do things against their will.

Similar data on victimization in Peruvian adolescents suggest $47.3 \%$ of children were victims of bullying at 8 years old, $30.4 \%$ at 12 years old, and $21.9 \%$ at 15 years old (Lister et al., 2015). However, a recent study analyzed 2015 data from a sample of 102.301 with 9th-grade students, from the National School Health Survey (PeNSE), indicating a lower prevalence of $8.8 \%$ in adolescents from 13 years old (Malta et al., 2019). Therefore, the inferences on the prevalence of bullying, especially in Brazil, should be performed with caution due to the cultural and socioeconomic differences in the country (Costa, Xavier, Andrade, Proietti, \& Caiffa, 2015).

\section{Witnessing bullying}

Regarding bystanders, a recent study conducted with a sample of 18.863 American teenagers showed a higher prevalence of bystanders willing to defend the victim (20.4\%) and only $9.7 \%$ of passive observers (Waasdorp \& Bradshaw, 2018). Such data differ from our results, as only five (3.2\%) adolescents reported helping their colleagues and $12(13.5 \%)$ reported having witnessed these behaviors without mentioning helping the colleague or reporting to someone.

\section{Defending bullied colleagues}

The divergence of opinion when choosing to help a colleague suffering bullied is multicausal. Among the causes are highlighted the interpretation of the situation (perception of bullying and its severity by the bystanders), social and moral evaluation (how the peers will react if they choose to defend their colleague), and the intervention effectiveness (I have enough strength/ respect towards the bully to do something?) (Thornberg et al., 2012).

Table 1.

Reporting frequency

\begin{tabular}{ccccc}
\hline \multirow{2}{*}{ Category } & \multicolumn{2}{c}{ Frequency } & \multicolumn{2}{c}{ Frequency according to sex } \\
\cline { 2 - 5 } & Total & Percentage & Male & Female \\
\hline $\mathbf{1}$ & 87 & $61,7 \%$ & $41(47,1 \%)$ & $46(52,8 \%)$ \\
$\mathbf{2}$ & 34 & $24,1 \%$ & $14(41,2 \%)$ & $20(58,8 \%)$ \\
$\mathbf{3}$ & 23 & $16,3 \%$ & $11(47,8 \%)$ & $12(52,1 \%)$ \\
$\mathbf{4}$ & 48 & $34 \%$ & $26(54,1 \%)$ & $22(45,8 \%)$ \\
\hline
\end{tabular}

Note: $\%$ - percentage referring to the total of valid testimonials $(n=141)$. 
Table 2.

Themes, sub-themes, and illustrative reports of the categories

\begin{tabular}{|c|c|c|}
\hline Categorias & Subcategories & Examples of Reports \\
\hline \multirow{13}{*}{1} & Suffering bullying & I have been bullied... \\
\hline & $(\mathrm{n}=70)$ & The bully assaulted me... \\
\hline & & My friends and colleagues make fun of me... \\
\hline & & I was excluded... \\
\hline & & I have been called by nicknames... \\
\hline & Witnessing & I witnessed when I was in 6th-grade.... \\
\hline & bullying & My 8-year-old brother has always been bullied because of his ears... \\
\hline & $(\mathrm{n}=12)$ & $\begin{array}{l}\text {...he was black and just for that reason he was discriminated against, he was death threat } \\
\text { and he had to move... }\end{array}$ \\
\hline & & I have witnessed many people kicking a person, cursing and torturing... \\
\hline & $\begin{array}{l}\text { Defending bullied } \\
\text { colleagues }\end{array}$ & $\begin{array}{l}\text {...everyone in my class made fun of him because of that, except me and my friends who } \\
\text { defended him... }\end{array}$ \\
\hline & $(\mathrm{n}=05)$ & I do everything to protect my brother, but sometimes I am not always with him... \\
\hline & & When I witnessed that scene, I even tried to go there to talk to them, but it did not help and \\
\hline & & I told the person to stop... \\
\hline \multirow{12}{*}{2} & Physical & ... because of the color of my skin... \\
\hline & characteristics & Because of my weight... \\
\hline & $(\mathrm{n}=24)$ & My height... \\
\hline & & ...because of my last name ... \\
\hline & & my appearance because the difference is strange for people... \\
\hline & & ... by the way I am ... \\
\hline & Showing & ... for being characterized as a "nerd"... \\
\hline & excellence or & ... when I do bomework... \\
\hline & $\begin{array}{l}\text { limitations in } \\
\text { studies } \\
(\mathrm{n}=03)\end{array}$ & ... because I was late for a school year ... \\
\hline & Sexual orientation & Because I am gay ... \\
\hline & $(\mathrm{n}=04)$ & Because my brother is gay ... \\
\hline & $\begin{array}{l}\text { Being introverted } \\
(\mathrm{n}=03)\end{array}$ & Because I am shy... \\
\hline \multirow{9}{*}{3} & Negative feelings & I got depressed all year, I was really sad... \\
\hline & $(n=9)$ & I feel bad and it also makes me very angry... \\
\hline & & I was very humiliated... \\
\hline & Psychosomatic & I can't concentrate on school activities \\
\hline & symptoms & I am indisposed to do something ... \\
\hline & $(n=10)$ & I was depressed, self-mutilated and diagnosed with bulimia months ago ... \\
\hline & $\begin{array}{l}\text { Damage to } \\
\text { social interaction }\end{array}$ & $\begin{array}{l}\text { I spent more than a month without leaving home and without doing what I like the most: } \\
\text { playing ball... }\end{array}$ \\
\hline & and school & I went home crying and even made up headaches to not go to school... \\
\hline & $\begin{array}{l}\text { performance } \\
(n=4)\end{array}$ & I delayed a school year ... \\
\hline
\end{tabular}


Table 2.

Themes, sub-themes, and illustrative reports of the categories (Continuation)

Talk to somebody Choose someone to tell how you feel...

$(n=11) \quad$ You should look for the school superior, a teacher or principal to try to solve this problem...

With my friends I bave overcome a lot...

I had a diary that I wrote everything, my mother read when I was at school, and when I got bome she talked to me...

Relying on faith One thing that helps me when I am down is to think about the text of Joshua 1, 19...

$(n=05)$

Acceptance

I am over it by going to church...

$(n=24)$

I believe that everyone deserves a second chance, including the aggressor...

4

Loving yourself first is very important...

If they were beaten, cursed, rejected, they would not like it...

Then every time I tell my friends to put themselves in his shoes

And each person must accept the opinion of others...

I accepted myself the way I am...

Be strong and

What matters is what you want, don't cry for things that aren't worth it

capable

$(n=08)$

Don't let this be stronger than you! Stay on your feet! No matter what they think or talke about you...

Turn suffering into a positive thing and never give up on dreams and move on ...

Finally, all the exposed reports suggest adolescents experienced physical, verbal/psychological, and relational bullying. However, these nomenclatures were not mentioned, using only the broader term bullying to refer to all their types. This fact suggests in certain regions of the country adolescents have greater knowledge about bullying. A study conducted in a public school in Porto Alegre/RS with 16 teachers and 60 students, from the 6th-grade of Elementary School and the 1st year of High School, school bullying was perceived by the focus groups as multifaceted, occurring mainly verbal and physical (Giordani, Seffner, \& Dell'Aglio, 2017). This hypothesis is also reinforced by international authors, suggesting adolescents tend to identify and present definitions of physical and verbal bullying, but rarely mentioning social exclusion and the imbalance of power favoring the aggressor (Byrne, Dooley, Fitzgerald, \& Dolphin, 2016).

\section{Reasons for bullying}

Regarding perception, the reasons why the adolescents suffer bullying can be grouped as follows: physical characteristics $(n=24)$, showing excellence or limitations in studies $(n=03)$, sexual orientation $(n=04)$, and being introverted $(n=03)$. These reasons were indicated by $24.1 \%$ of the sample.

\section{Physical characteristics}

The findings of this study suggest one of the most common bullying is the use of nicknames, corroborated by other authors (Giordani et al., 2017). This type of bullying usually generates laughter in peers, which contributes to the naturalization of this form of violence being considered something normal (Santos \& Rodrigues, 2013).

\section{Showing excellence or limitations in studies}

Although reports of bullying related to aptitudes in studies are common in the literature (Byrne et al., 2016; Thornberg et al., 2012), in this study only three adolescents reported this type of bullying. A possible explanation for this discrepancy is cultural differences (Costa et al., 2015; Smith, López-Castro, \& Görzig, 2019). The scarcity of studies addressing the perception of bullying in the northern region of Brazil prevents comparisons and preparation of possible explanations for this finding. 


\section{$\underline{\text { Sexual orientation }}$}

Four of the adolescents reported being bullied due to their sexual orientation or for knew/lived with a homosexual. Although these alarming findings, unfortunately, such reports are common in the literature, often sexual minorities, especially young people, are victims of bullying and violence more often than heterosexuals (Coulter, Herrick, Friedman, \& Stall, 2016; Mueller, James, Abrutyn, \& Levin, 2015). The presence of suicidal ideation and self-mutilation with or without suicidal intent is more common, a result of bullying in sexual minorities (Mueller et al., 2015). This data was also corroborated in our study since most reports of self-mutilation and suicidal ideation were mentioned by homosexual victims of bullying.

Furthermore, the elements commonly described in the literature as associated with bullying (i.e. intention, repetition, and power imbalance) were not mentioned in the reports. This suggests a discrepancy between the conceptualization made by researchers and the perception of students. This issue was observed in Swedish adolescents (Frisén, Holmqvist, \& Oscarsson, 2008), suggesting caution when using nomenclatures associated with forms of bullying. Thus, bullying intervention strategies are personalized to each population, starting with a qualitative study that investigates the perception of adolescents on the phenomenon, thus a strategy developed/adapted for the group of adolescents studied (Byrne et al., 2016).

In this study, girls frequently reported the reasons associated with bullying (58.8\%). Such findings contradict some authors, suggesting usually boys tend to describe more the reasons and types of bullying experienced, while girls tend to talk more about the consequences (Frisén et al., 2008). However, another study concluded no differences regarding gender after evaluating samples from 14 countries (Smith, Cowie, Olafsson, \& Liefooghe, 2002). This divergence of opinions highlights the need for further studies addressing this issue, especially after robust current data suggests that gender differences in bullying tend to vary culturally (Smith et al., 2019).

\section{Consequences of bullying}

Of the 141 adolescents, $16.3 \%$ mentioned the consequences of bullying in their testimonies. According to the perception, the consequences of bullying are related to negative feelings $(n=9)$, psychosomatic symptoms $(n=10)$, and damage to social interaction and school performance $(n=4)$.

\section{Negative feelings}

In the view of adolescents, the immediate consequences of bullying are related to feelings of sadness, anger, shame, and humiliation. Few studies investigate the feelings involved in bullying (Slonje, Smith, \& Frisén, 2017). However, the findings of this study are in line with the existing literature, indicating mainly anger, followed by sadness, shame, and loneliness as immediate consequences of bullying (Ortega et al., 2012). Thus, in cases where bullying is recurrent, these feelings can become persistent, increasing the chance for the development of long-term psychosomatic symptoms and psychological illnesses (Slonje et al., 2017).

\section{Psychosomatic symptoms}

Psychosomatic symptoms such as indisposition, headaches, and depressive symptoms were mentioned by adolescents. These findings are in line with the current literature, indicating that adolescents who suffer bullying tend to initially have negative feelings, followed by psychosomatic symptoms (e.g. body pain, selfmutilation). Therefore, developing the possibility of psychological diseases such as depression and anxiety (Ortega et al., 2012; Slonje et al., 2017; UNICEF, 2017), in addition to suicidal thoughts and interpersonal difficulties (UNICEF, 2017).

\section{Damage to social interaction and school performance}

Losses in interpersonal relationships are usually related to social isolation. This avoidance behavior is commonly reported in the literature and understood as a maladaptive coping strategy, not solving the problem, but just avoiding it (Ortega et al., 2012).

In addition, bullying directly interferes with the learning ability of the victims, as the suffering caused, as well as the expectation of being bullied again, hinders the ability to concentrate (Clemmensen et al., 2018). Prejudice, discrimination, nicknames, humiliation, and threats were observed to directly interfere in the psychological aspect of adolescents, often excluding them from the school environment. In these cases, the school is not a pleasant environment for human interaction and training, or for promoting knowledge, but a place of violence and exclusion (Santos \& Rodrigues, 2013).

\section{Coping strategies and self-compassion expressions}

This category registers: a) strategies for coping with bullying used by adolescents (i.e. talk to somebody and supporting themselves in faith) and b) self-compassion expressions suggested in messages to colleagues 
who are bullied as a form of coping (i.e. acceptance and being strong and capable ).

According to the perception of $11.3 \%(n=16)$ adolescents, the strategies talk to somebody (e.g. friends, family, school staff), and relying on faith helped to overcome bullying. The feelings of acceptance themselves and hope were internalized by them. Such feelings are in line with the criteria of emotional self-regulation. These results agree with a study by Zappe and Dell'Aglio (2016) on risk and protection in adolescence in different contexts. The study highlighted that adolescent engagement in risky behaviors is related to contextual protective factors such as family, peer group, and social support network, especially school and religion.

\section{Talk to somebody}

Boulton M. and Boulton L. (2017) stated that many young people do not tell anyone about being bullied and the victims lack social support. Disclosure is essential for developing and practicing intervention strategies against bullying, helping teenagers to deal with any negative feelings. In this context, true and lasting friendships contribute to the development of prosocial behavior, a coping strategy to overcome violence. In the relationship between peers, adolescents learn to dialogue, express their opinions, and listen to the opinion of a friend even if they do not agree.

In this sense, a qualitative study that investigated coping strategies for children $(n=16)$ victims and nonvictims of bullying, showed the most mentioned coping strategy was the search for social support $(68.8 \%)$. This category considered the importance of having a person to help with the bullying situation (e.g. mother, friends, and siblings). The authors emphasize the fact that children are more dependent on other people to solve their problems, thus children admit more easily the help from adults (Braga \& Lisboa, 2010).

Regarding family support, the longitudinal findings of Duggins, Kuperminc, Henrich, Smalls-Glover and Perilla (2016) identified family connectivity emerged as a potentially important protective factor for aggressive behavior among victims of school bullying. The connection with the parents helps adolescents positively with the stressful experience of victimization, enabling the recovery of the adverse experience. However, in contrast to the results of the family connection, support from adults and peers at school had neither positive nor protective effects. In this case, adult support at school could increase vulnerability in the view of students who have suffered victimization over time.

\section{Relying on faith}

According to the testimonies, the use of faith as a strategy to confront bullying was mentioned in only ( $n$ $=5)$ reports. The adolescents referred to biblical passages about the idea that God helps those who were suffering, one of the foundations of the Christian vision. No other studies were found indicating the use of this type of strategy by adolescents from Brazilian victims of bullying.

However, in South Africa a study on cyberbullying and spirituality, conducted by Apostolides (2017), concluded spirituality can prevent cyberbullying and even help children and young people to heal from the trauma caused by this type of virtual bullying. In Australia, Raftopuolos and Bates (2011) investigated adolescents and spirituality based on a structured interview $(n=$ 15). The authors identified spirituality is an essential aspect of adolescence, especially regarding resilience and support for recovery in times of difficulty. In the survey, the adolescents explained that spirituality provided a sense of protection, security, and comfort. This statement, although not directly related to overcoming bullying, agrees with the statements of the adolescents in this study. The participants expressed that security and protection from faith in God helped to overcome the impacts of bullying.

However, the number of reports on coping strategies in this study was low, only 16 of 141 adolescents reported possible ways to face bullying. Therefore, psychoeducational intervention strategies, with a focus on strategies to cope with bullying, are necessary to assist adolescents in coping with such situations.

\section{Acceptance}

The emergence of self-compassion expressions of acceptance was recorded in $(n=24)$ reports of adolescents in line with the self-compassionate element of self-kindness. According to Neff and Germer (2019), self-kindness combats the tendency towards recrimination, allowing individuals to be kind to themselves when experiencing a problem, such as when treating a close friend during a difficult experience (for example, feeling inadequate at school).

The "combating recrimination" is defined as a form of coping strategy, since theoretical reviews on coping suggest the use of strategies, by an individual, as a way to face a stressful situation (Antoniazzi, Dell'Aglio, \& Bandeira, 1998; Pietrowski, Cardoso, \& Bernardi, 2018). Thus, when writing a message to a colleague who had suffered bullying, approximately $17 \%$ 
$(n=24)$ of the adolescents presented a proposal for self-compassion coping.

Adolescents tend to experience feelings of loneliness, sadness, and feelings of inadequacy. Therefore, through the resources of self-compassion, adolescents can improve their self-esteem (Bluth, 2017). Thus, students believe they are not alone in their experience of bullying, despite feeling inadequate, they are not potentially affected by bullying. Students with lower levels of self-compassion can be more self-critical and, in order to feel better, eventually influence peers to bully others (Gonynor, 2016).

\section{Be strong and capable}

Only eight of the adolescents wrote some motivational phrases for their colleagues. Such motivational phrases are in line with the concept of self-appreciation, characterized to correct the negative bias towards the maturation of perception. Self-appreciation is influenced by the social environment and, therefore, also extends to those willing to assist the development of positive perception in adolescents (e.g. parents, friends, and teachers) (Neff \& Germer, 2019).

\section{Final considerations}

This article aimed to investigate the narratives of bullying and the expression of self-compassion as a possible coping strategy in adolescents. The main findings indicate $61.7 \%$ of adolescents suffered or witnessed bullying at school. Only $34 \%$ used some coping strategies to try to overcome the suffering caused. However, most of these strategies were related to selfcompassion (66.7\%).

The testimonies of the adolescents presented contents related to self-compassion even before the psychoeducational explanation/intervention of the concept. Thus, talk to somebody, accepting oneself, encouraging oneself and encouraging others to be strong and capable, relying on faith (with or without a religious institution) are coping strategies related to self-compassion that can support adolescent victims of bullying.

These results allow the inference that the use of psychoeducational interventions, about topics related to self-compassion and bullying, can raise awareness about the harms of bullying to health, individual and collective well-being. In addition, assist in the development of self-compassionate coping strategies. This type of intervention presents a promising character, positively impacting the biopsychosocial well-being of adolescents. Thus, teachers and mediating students are involved in this challenge of building a less violent school.

Regarding possible gender differences, the only significant variation considered the perception of the reasons related to bullying, with a predominance of reports from girls. Although this finding agrees with the international literature, new studies should investigate this variable deeply in Brazilian adolescents, especially from northern Brazil, due to the scarcity of studies on bullying with this population.

Future studies should search for greater heterogeneity with randomized samples. This suggestion is based on the main limitation of this study, since the groups were selected by convenience, grades, and class. This heterogeneous approach made it impossible to obtain more comprehensive data on the experiences of bullying and possible coping strategies.

In addition, the cross-sectional nature of this study might be considered a limitation. The relationship between the testimonies of adolescents before and after the psychoeducational intervention was not possible to establish. Therefore, it is important that new longitudinal studies collect reports from adolescents on bullying and self-compassion, in the pre- and post-test of a psychoeducational intervention, looking for possible changes over time and controlling for age, gender, and bullying experiences.

\section{References}

Antoniazzi, A. S., Dell'Aglio, D. D., Bandeira, D. R. (1998). O conceito de coping: uma revisão teórica. Estudos de Psicologia, 3(2), 273-294. doi: https://doi. org/10.1590/S1413-294X1998000200006

Apostolides, A. (2017). Cyber bullying: Child and youth spirituality. HTS Theological Studies,73(3), 1-7.doi: https://doi.org/10.4102/hts.v73i3.4692

Bardin, L. (2016). Análise de Conteúdo. São Paulo: Edições 70. (Original publicado em 1977)

Bluth, K. (2017). The Self-Compassion: workbook for tens. Oakland, California: Instant Help Books.

Boulton, M. J., \& Boulton, L. (2017). Modifying selfblame, self-esteem, and disclosure through a cooperative cross-age teaching intervention for bullying among adolescents. Violence and Victims, 32(4), 609-626. doi: https://doi.org/10.1891/0886-6708. VV-D-15-00075 
Braga, L. L., \& Lisboa, C. (2010). Estratégias de coping para lidar com o processo de bullying: um estudo qualitativo. Interamerican Jounal of Psychology, 44(2), 321-331. Recuperado de https:/ /www.redalyc.org/ articulo.oa?id $=28420641013$

Byrne, H., Dooley, B., Fitzgerald, A., \& Dolphin, L. (2016). Adolescents' definitions of bullying: The contribution of age, gender, and experience of bullying. European Journal of Psychology of Education, 31(3), 403-418. doi: https://doi.org/10.1007/ s10212-015-0271-8

Clemmensen, L., Jepsen, J. R. M., Van Os, J., BlijdHoogewys, E. M., Rimvall, M. K., Olsen, E. M., ... \& Jeppesen, P. (2018). Are theory of mind and bullying separately associated with later academic performance among preadolescents?. British Journal of Educational Psychology, 90(1), 62-76. doi: https:// doi.org/10.1111/bjep.12263

Costa, M. R. D., Xavier, C. C., Andrade, A. C. D. S., Proietti, F. A., \& Caiaffa, W. T. (2015). Bullying among adolescents in a Brazilian urban center-"Health in Beagá" Study. Revista de Saúde Pública, 49(56), 1-10. doi: https:/ / doi.org/10.1590/ S0034-8910.2015049005188

Coulter, R. W., Herrick, A. L., Friedman, M. R., \& Stall, R. D. (2016). Sexual-orientation differences in positive youth development: The mediational role of bullying victimization. American Journal of Public Health, 106(4), 691-697. doi: https://doi. org/10.2105/AJPH.2015.303005

Duggins, S. D., Kuperminc, G. P., Henrich, C. C., Smalls-Glover, C., \& Perilla, J. L. (2016). Agressão entre adolescentes vítimas de bullying escolar: papéis protetores da família e da conexão escolar. Psychology of Violence, 6(2), 205-212. doi: https:// doi.org/10.1037/a0039439

Fikkers, K. M., Piotrowski, J. T., Lugtig, P., \& Valkenburg, P. M. (2016). The role of perceived peer norms in the relationship between media violence exposure and adolescents aggression. Media Psychology, 19(1), 4-26. doi: https://doi.org/10.1080/ 15213269.2015.1037960

Frisén, A., Holmqvist, K., \&Oscarsson, D. (2008). 13 year-olds' perception of bullying: definitions, reasons for victimisation and experience of adults' response. Educational Studies, 34(2), 105-117. doi: https://doi.org/10.1080/03055690701811149
García-Campayo, J., Martí, A. C., \& Demarzo, M. M. P. (2018). A ciência da compaixão. São Paulo: Palas Athena.

Giordani, J. P., Seffner, F., \& Dell'Aglio, D. D. (2017). Violência escolar: percepções de alunos e professores de uma escola pública. Psicologia Escolar e Educacional,21(1), 103-111.doi: https://doi. org/10.1590/2175-3539201702111092

Gonçalves, F. V., Cardoso, N. O., \& Argimon, I. I. L. (2019). Estratégias de intervenção para adolescentes em situações de bullying escolar: uma revisão sistemática. Contextos Clínicos, 12(2), 636-658. doi: https://doi.org/10.4013/ctc.2019.122.12

Gonynor, K. A. (2016). Associations among mindfulness, self-compassion, and bullying in early adolescence (Doctoral Thesis). Colorado State University. Colorado, United States. Recuperado de http://hdl.handle.net/10217/176658

Lister, C. E., Ray, M. M., Vance, D. L. Joshua, H. W. Parley, C. H., \& Benjamin, T. C. (2015). Victimization among Peruvian adolescents. Journal of School Health,85(7),413-496.doi: https://doi. org/10.1111/josh.12271

Livingston, M. D, Rossheim, M. E \& Hall, K. S. (2019). A descriptive analysis of school and school shooter characteristics and the severity of school shootings in the United States. Journal of Adolescent Health, 64(6), 797-799. doi: https://doi.org/10.1016/j. jadohealth.2018.12.006

Malta, D. C., Mello, F. C. M., Prado, R. R., Sá, A. C. M. G. N., Marinho, F., Pinto, I. V., ... \& Silva, M. A. I. (2019). Prevalência de bullying e fatores associados em escolares brasileiros. Ciência \& Saúde Coletiva, 24(4), 1359-1368. doi: https://doi. org/10.1590/1413-81232018244.15492017

Marcuschi, L. A. (2010). Da fala para a escrita: atividades de retextualização. São Paulo: Cortez.

Matischek-Jauk, M., Krammer, G., \& Reicher, H. (2017). The life-skills program Lions Quest in Austrian schools: implementation and outcomes. Health Promotion International, 33(6), 1022-1032. doi: https:/ / doi.org/10.1093/heapro/dax050

Mueller, A. S., James, W., Abrutyn, S., \& Levin, M. L. (2015). Suicide ideation and bullying among US adolescents: Examining the intersections of sexual orientation, gender, and race/ethnicity. Psico-USF, Bragança Paulista, v. 26, n. 3, p. 495-506, jul./set. 2021 
American Journal of Public Health,105(5), 980-985. doi: https://doi.org/10.2105/AJPH.2014.302391

Naidoo, S., Satorius, B. K., Vries, H., \& Taylor, M. (2016). Verbal bullying changes among students following an educational intervention using the integrated model for behavior change. Journal of School Health, 86(11), 813-822. doi: https://doi. org/10.1111/josh.12439

Neff, K., \& Germer, C. (2019). Manual de mindfulness e autocompaixão: um guia para construir forças internas e prosperar na arte de ser seu melhor amigo. Porto Alegre: Artmed.

Ortega, R., Elipe, P., Mora-Merchán, J. A., Genta, M. L., Brighi, A., Guarini, A., ... Smith, P. K. (2012). The emotional impact of bullying and cyberbullying on victims: A European cross-national study. Aggressive Behavior, 38(5), 342-356. doi: https:// doi.org/10.1002/ab.21440

Petrucci, G. W., \& Borsa, J. C (2016). Contribuições da psicologia positiva para a compreensão do bullying escolar. Em B. L. Seibel, M. Poleto \& S. H. Koller (orgs.), Psicologia Positiva: teoria, pesquisa e intervenção (pp. 289-304). Porto Alegre: Juruá.

Pietrowski, D. L., Cardoso, N. O., \& Bernardi, C. C. N. (2018). Estratégias de coping frente à síndrome de burnout entre os professores: Uma revisão integrativa da literatura nacional. Contextos Clínicos, 11(3), 397-409. doi: https://doi.org/10.4013/ ctc. 2018.113 .10

Pigozi, P. L., \& Machado, A. L. (2015). Bullying na adolescência: Visão panorâmica no Brasil. Ciência \& Saúde Coletiva, 20(11), 3509-3522. doi: https://doi. org/10.1590/1413-812320152011.05292014

Pureza, J. R., Marin, A. H., \& Lisboa, C. S. M. (2017). Intervenções para o fenômeno bullying na infância: uma revisão sistemática da literatura. Interação em Psicologia, 20(3). 341-352. doi: https:// doi.org/10.5380/psi.v20i3.34995

Raftopuolos, M. \& Bates, G., (2011). '"It's knowing that you are not alone": The role of spirituality in adolescent resilience, International Journal of Children's Spirituality 16(2), 151-167. doi: https://doi.org/10. 1080/1364436X.2011.580729

Rodrigues, M. (2015). Baralho das forças pessoais: A Psicologia Positiva aplicada às crianças. Novo Hamburgo: Sinopsys.
Santos, J. M., \& Rodrigues, P. J. M. (2013). O diálogo como possibilidade de mediação da violência na escola. Práxis Educativa, 8(1), 273-294. doi: https:// doi.org/10.5212/PraxEduc.v.8i1.0011

Slonje, R., Smith, P. K., \&Frisén, A. (2017). Perceived reasons for the negative impact of cyberbullying and traditional bullying. European journal of developmental psychology, 14(3), 295-310. doi: https://doi.or $\mathrm{g} / 10.1080 / 17405629.2016 .1200461$

Smith, P. K., López-Castro, L., Robinson, S., \& Görzig, A. (2019). Consistency of gender differences in bullying in cross-cultural surveys. Aggression and Violent Behavior, 45, 33-40. doi: https://doi. org/10.1016/j.avb.2018.04.006

Smith, P. L., Cowie, H., Olafsson, R., \& Liefooghe, A. (2002). Definition of bullying: a comparison of terms used, and age and sex differences in a 14 country international comparison. Child Development, 73(4), 1119-1133. doi: https://doi. org/10.1111/1467-8624.00461

Snyder, C. R., \& Lopez, S. J. (2009). Psicologia Positiva: uma abordagem cientifica e Prática das qualidades humanas. Porto Alegre: Artmed.

Thornberg, R., Tenenbaum, L., Varjas, K., Meyers, J., Jungert, T., \& Vanegas, G. (2012). Bystander motivation in bullying incidents: To intervene or not to intervene? Western Journal of Emergency Medicine, 13(3), 247. doi:https://doi.org/10.5811/ westjem.2012.3.11792

United Nations Children's Fund. (2017). A familiar face: violence in the lives of children and adolescents. New York. Recuperado de https://www.unicef.org/publications/index_101397.html

Waasdorp, T. E., \& Bradshaw, C. P. (2018). Examining variation in adolescent bystanders' responses to bullying. School Psychology Review, 47(1), 18-33. doi: https://doi.org/10.17105/SPR-2017-0081. V47-1

Zappe, J. G., \& Dell'Aglio, D. D. (2016). Adolescência em diferentes contextos de desenvolvimento: risco e proteção em uma perspectiva longitudinal.Psico,47(2), 99-110.doi: https://doi. org/10.15448/1980-8623.2016.2.21494

Zhang, H., \& Wang, Y. (2019). Bullying victimization and depression among young Chinese adults with physical disability: Roles of gratitude and 
self-compassion. Children and Youth Services Review, 103, 51-56. doi: https://doi.org/10.1016/j. childyouth.2019.05.035
Recebido em: 18/07/2019

Reformulado em: 19/08/2020

Aprovado em: 14/09/2020

Acknowledgments:

Agradecimentos: Este estudo foi financiado em parte pela Coordenação de Aperfeiçoamento de Pessoal de Nível Superior - Brasil (CAPES) e pelo Conselho Nacional de Desenvolvimento Científico e Tecnológico (CNPq) - código de financiamento 001

About the authors:

Francisca Valda Gonçalves - Graduation in Portuguese Letters/Literature (UNIR, 2003); Specialization in Higher Education Teaching (UCAM, 2005); Master in Language Sciences (UNIR, 2009); PhD in Psychology (PUCRS/FCR, 2019) with scholarship SEDUC/RO, institution where she is a teacher of Basic Education.

ORCID: https://orcid.org/0000-0003-0443-3826

E-mail:vandavalda@gmail.com

Nicolas de Oliveira Cardoso - Psychologist (ULBRA, 2017), Master in Clinical Psychology (PUCRS, 2019). PhD student in clinical psychology in the Research Group Avaliação em Bem-estar e Saúde Mental (PUCRS).

ORCID: https://orcid.org/0000-0002-1555-1409

E-mail: nicolas.deoliveira@hotmail.com

Irani Iracema de Lima Argimon - Psychologist (PUCRS, 1979), Master in Education (PUCRS, 1997) and PhD in Psychology (PUCRS, 2002). Full Professor and coordinator of the Graduate Program in Psychology and the Research Group Avaliação e Intervenção no Ciclo Vital (PUCRS).

ORCID: https://orcid.org/0000-0003-4984-0345

E-mail:argimoni@pucrs.br

Correspondence With The Editor

E-mail:nicolas.deoliveira@hotmail.com

Contact:

Ipiranga Avenue, 6681 - Building 11 - 9 floor, Partenon

Porto Alegre-RS, Brazil

CEP: 90619-900 